\begin{tabular}{|cl}
\hline Jurnal Teknologi Kimia Unimal & $\begin{array}{l}\text { Jurnal } \\
\text { Teknologi } \\
\text { Kimia } \\
\text { Unimal }\end{array}$ \\
\hline
\end{tabular}

\title{
Analisa Laju Korosi Baja Karbon ST-37 dalam Larutan Asam Sulfat dengan Penambahan Inhibitor Ekstrak Daun Tembakau
}

\author{
Ishak $^{1}$, Jalaluddin ${ }^{1}$, Zainuddin Ginting ${ }^{1}$, Fitra Rahmatika ${ }^{1}$ \\ ${ }^{1}$ Jurusan Teknik Kimia, Fakultas Teknik, Universitas Malikussaleh \\ Jln. Batam No. 2 Bukit Indah Lhokseumawe 24355 \\ email: ishgi@yahoo.co.id
}

\begin{abstract}
Abstak
Studi penggunaan ekstrak daun tembakau (inhibitor) sebagai penghambat korosi baja karbon dilakukan pada penelitian di laboratorium dengan menggunakan metode perendaman. Media korosif untuk perendaman merupakan larutan asam sulfat telah ditambahkan inhibitor. Inhibitor yang digunakan merupakan esktrak daun tembakau kering. Perendaman dilakukan dalam rentang waktu 3, 6, 9, 12 dan 15 hari dengan menggunakan inhibitor 0, 4, 6 dan $\mathrm{ml} / \mathrm{l}$ larutan asam sulfat. Penelitian menunjukkan bahwa serangan korosi diperuntukkan baja karbon, maka laju korosi dapat ditentukan dengan metode kehilangan berat. Perkiraan besarnya laju korosi dari hasil penelitian yang diperoleh pada baja karbon dalam lingkungan asam sulfat dengan penambahan inhibitor ekstrak daun tembakau, ternyata ketahanan korosi dapat meningkat secara signifikan. Peningkatan konsentrasi inhibitor dan lamanya waktu perendaman mengakibatkan terbentukan lapisan tipis (film) protektif di permukaan baja, sehingga menghambat kontak langsung antara baja karbon dengan lingkungan. Laju korosi terendah dan efisiensi inhibisi tertinggi diperoleh pada perendaman 15 hari dengan konsentrasi inhibitor $8 \mathrm{ml} /$ liter larutan masing yaitu 5,7 mpy dan 66,27\%.
\end{abstract}

Kata kunci: baja karbon, korosi, inhibitor, efisiensi, laju korosi

\section{Pendahuluan}

Peristiwa korosi pada dasarnya telah dikenal di Indonesia dan juga di negara-negara lain. Pada kehidupan sehari-hari, korosi dapat dijumpai pada berbagai jenis peralatan, misalnya peralatan konstruksi yang memakai komponen logam. seperti seng, tembaga, kuningan, aluminium, besi baja bahkan stainless steel, semuanya dapat terserang oleh korosi. Permasalah ini secara ilmiah belum tuntas terjawab sehingga saat ini selain merupakan masalah perlakuan permukaan yang merupakan kajian dan perlu ditangani secara fisika, korosi juga menyangkut 
kinetika reaksi yang menjadi wilayah kajian para ahli kimia. Korosi juga menjadi masalah ekonomi karena menyangkut umur, penyusutan dan kehilangan berat serta pemakaian suatu bahan maupun peralatan dalam kegiatan industri. Permasalahan korosi di Indonesia perlu mendapat perhatian serius mengingat dua pertiga wilayah nusantara terdiri dari lautan dan terletak di daerah tropis dengan curah hujan tinggi dan kandungan senyawa klorida yang tinggi (Asdim, 2002).

Menurut Trethewey (1991), salah satu faktor yang mempengaruhi korosi dalam lingkungan air adalah keberadaan elektrolit. Contohnya adalah asam sulfat dan natrium klorida, kedua senyawa tersebut merupakan elektrolit kuat. Dan jenis logam yang banyak digunakan untuk bahan konstruksi bangunan adalah baja. Penelitian ini menguji bagaimana laju dari korosi baja dalam perendaman pada larutan asam sulfat.

Inhibitor korosi adalah suatu zat kimia yang dipakai untuk menurunkan laju korosi pada logam secara efisien. Proses inhibasi ini dilaksanakan dengan 2 metode yakni inhibasi antarmuka dan inhibasi antarfase. Inhibasi antarmuka adalah suatu proses perlindungan terhadap logam dengan teknik pembentukan lapisan oksida yang akan mengayomi logam dari korosi. sementara inhibasi antarfase adalah upaya pencegahan terhadap korosi dengan teknik menetralkan lingkungan yang korosif dengan menambahkan zat-zat kimia tertentu. Dalam spesies nicotiana tabacum terdapat varietas yang amat banyak jumlahnya, dan untuk tiap daerah terdapat perbedaan jumlah kadar nikotin, bentuk daun, dan jumlah daun yang dihasilkan. Proporsi kadar nikotin banyak bergantung kepada varietas, tanah tempat tumbuh tanaman, dan kultur teknis serta proses pengolahan daunnya (Abdullah, 1982).

\section{Metode Penelitian}

Penelitian ini menggunakan bahan ekstrak daun tembakau sebagai inhibitor, dan larutan asam sulfat sebagai media untuk memaparkan baja karbon. Sedangkan peralatan yang digunakan pada adalah $\mathrm{pH}$-meter, timbangan digital, beaker glass, desikator, oven, peyaring, spatula, tali, blender, pisau dan kertas 
abarsif grid 400-1000. Kemudian dipesiapkan dalam suatu rancangan untuk melakukan percobaan, serta dilakukan penyusunan prosedur kerja.

Pengukuran laju korosi dengan metode perendaman di lakukan sesuai dengan prosedur, mulai dari tahap persiapan sampel, tahap ekstrak daun tembakau, tahap persiapan larutan korosif, dan perendaman dalam larutan $\mathrm{H}_{2} \mathrm{SO}_{4}$ sesuai dengan variabel yang di variasikan. Persiapan logam yang teliti adalah pelat baja carbon rendah ST-37 dan di potong dengan ukuran 3,7 x 3,5 x 0,3 cm dan diberi lubang untuk penggantung. Pelat yang sudah dipotong di amplas dengan kertas abrasif hingga grit 1200. Lalu di cuci dengan etanol untuk menghilangkan lemak yang menempel. Plat yang sudah bersih dikeringkan dalam oven lalu di didinginkan dalam desikator dan di ukur kembali luas yang sebenarnnya.

Ekstrak daun tembakau sebanyak 250 gr dilarutkan kedalam $1500 \mathrm{~mL}$ aquades dengan suhu $80^{\circ} \mathrm{C}$ didiamkan selama 24 jam. Larutan media korosif asam sulfat $1 \mathrm{M}$ dibuat dari asam sulfat dengan cara mengencerkan sebanyak 2,8 $\mathrm{mL}$ asam sulfat dalam labu ukur $50 \mathrm{~mL}$ sampai tanda batas. Kemudian logam dirangkaikan dalam suatu sistem percobaan dengan cara perendaman logam tersebut dalam larutan asam sulfat $1 \mathrm{M}$. Variabel yang divariasikan adalah konsentrasi inhibitor: 0, 4, 6 dan $8 \mathrm{ml} / \mathrm{l}$ larutan dan waktu perendaman : 3, 6, 9, 12, dan 15 hari.

Metode perendaman dalam larutan korosif yang telah dipersiapkan tersebu, dan sampel (baja) yang telah diukur luas permukaannya dan di timbang. Kemudian direndam dalam larutan korosif yang telah ditambahkan inhibitor dan yang tidak ditambhakan inhibitor. Konsentrasi inhibitor dan waktu perendaman dilakukan sesuai dengan variasi yang telah ditetapkan. Selama perendaman dilakukan pengukuran $\mathrm{pH}$. Setelah waktu perendaman tercapai, sampel (baja) di cuci dengan larutan etanol untuk menghilangkan produk korosi yang menempel lalu dibilas menggunakan aquades, lalu dikeringkan dalam oven. Kemudian didinginkan di desikator lalu dilakukan penimbangan dan dicatat perubahan berat yang terjadi. 
Data yang diperoleh dari hasil pernelitian dilakukan perhitungan laju korosi baja karbon serta efesiensi inhibitor. Adapun prosedur pelaksanaannya penelitian diillustrasikan dalam Gambar 1. Korosi baja dalam larutan asam sulfat merupakan reaksi elektrokimia antara baja karbon dengan lingkungan melibatkan perpindahan elektron dan logam teroksidasi menjadi ionnya. Dalam penelitian ini serangan korosi terjadi secara merata di permukaan logam, laju korosi dapat ditentukan dengan metode kehilangan berat. Pada metode ini, besarnya laju korosi dinyatakan sebagai besarnya kehilangan berat benda uji per satuan luas permukaan per satuan waktu perendaman (Noviadam., M.R \& Sakti A.M. 2016). Data dihasilkan berdasarkan perhitungan menggunakan persamaan, untuk menghitung laju korosi:

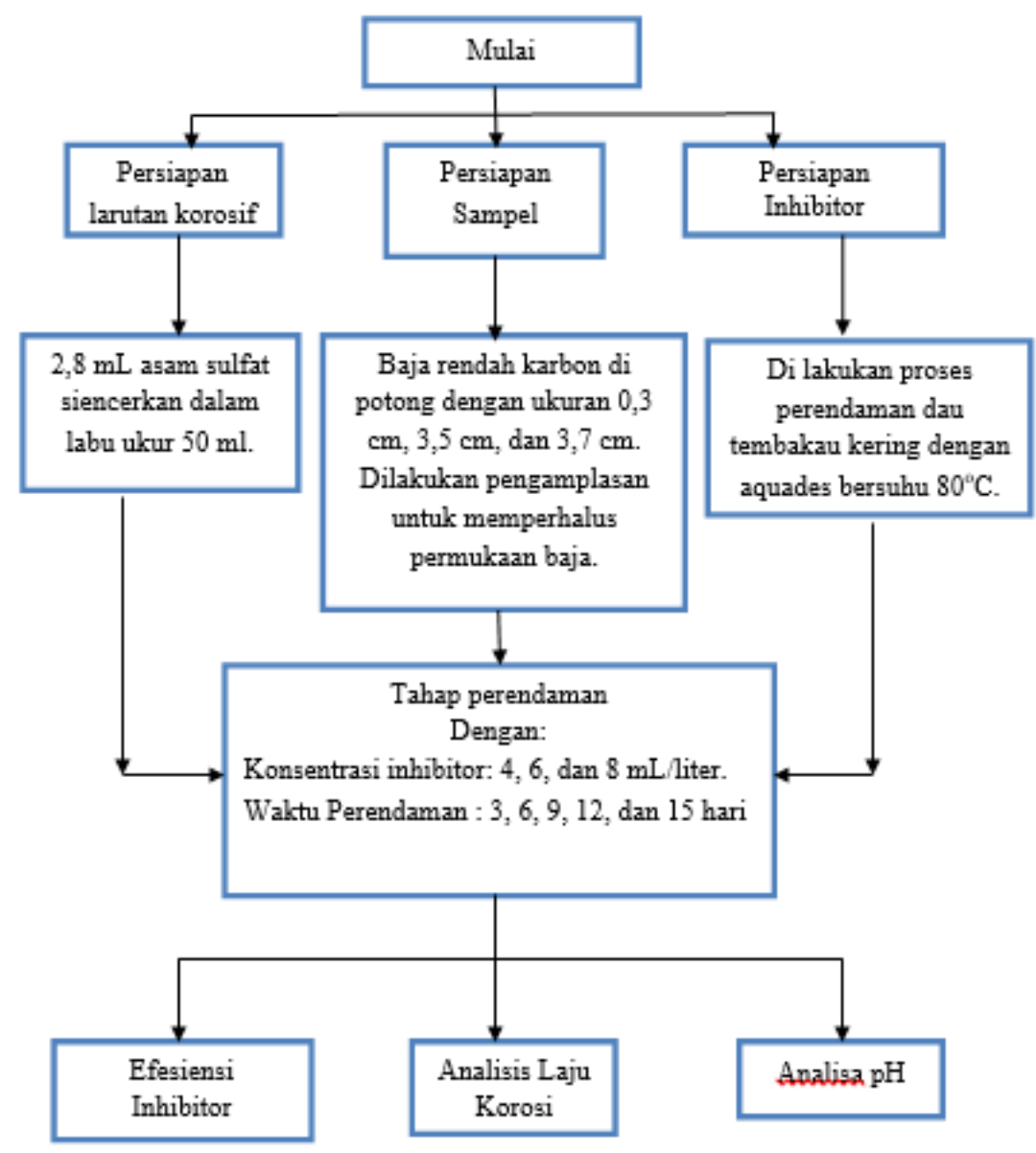

Gambar 1. Bagan Alir Prosedur Pelaksanaan Penelitian 


$$
r=\frac{534 \mathrm{~W}}{\mathrm{DAt}}
$$

dimana: $r$ = Laju Korosi (mpy),

$\mathrm{W}=$ Kehilangan berat $(\mathrm{mg})$,

$\mathrm{D}=$ Densitas Larutan Korosif $\left(\mathrm{gr} / \mathrm{cm}^{3}\right)$,

$\mathrm{A}=$ luas penampang spesimen $\left(\mathrm{in}^{2}\right)$,

$\mathrm{t}=$ waktu perendaman $(\mathrm{jam})$

Untuk menghitung efisiensi inhibitor menggunakan rumus:

Efisiensi Inhibitor $=\left[\left(\mathrm{r}_{\text {unhibited }}-\mathrm{r}_{\text {inhibited }}\right) /\left(\mathrm{r}_{\text {inhibited }}\right)\right] \times 100 \%$

dimana: $\quad r_{\text {unhibited }}=$ laju korosi pada sistem yang tidak terinhibisi,

$\mathrm{r}_{\text {inhibited }}=$ laju korosi pada sistem yang terhinbibisi.

\section{Hasil dan Pembahasan}

Pengaruh konsentrasi ekstrak daun tembakau terhadap laju korosi baja dalam lingkungan asam diperlihatkan pada gambar 2. Grafik tersebut menjelaskan bahwa laju korosi baja karbon rendah dalam lingkungan asam menurun secara signifikan dengan peningkatan konsentrasi ekstrak daun tembakau dan lama waktu perendaman. Dalam waktu perendaman 3 hari menunjukkan bahwa penurunan laju korosi masih relatif lambat, namun dengan meningkatnya waktu perendaman, penurunan laju korosi semakin cepat dan relatif stabil. Penurunan laju korosi terbaik dalam penelitian ini diperoleh pada perendaman 15 hari dan inhibitor $8 \mathrm{ml} / \mathrm{L}$. Penurunan ini diakibatkan pembentukan lapisan tipis protektif di permukaan baja sehingga menghambat kontak antara baja karbon rendah dengan lingkungan secara langsung, lapisan tipis (film) protektif terbentuk karena adsorpsi molekul-molekul organik rantai panjang yang melekat pada permukaan baja karbon rendah. Molekul-molekul ini dapat membatasi difusi oksigen ke permukaan atau memerangkap ion-ion logam di permukaan, memantapkan lapisan ganda, dan mereduksi laju pelarut (Ishak Ibrahim, 2004). Bentuk lapisan pasif yang menghalangi ion-ion korosif masuk ke permukaan baja adalah berupa 
lapisan oksida besi yang menempel pada permukaan baja. Selaput pasif tipis atau lapisan-lapisan garam yang kemudian menyelimuti anoda akan menghalangi serangan ion-ion korosif pada pada permukaan baja (Threthewey, 1991).

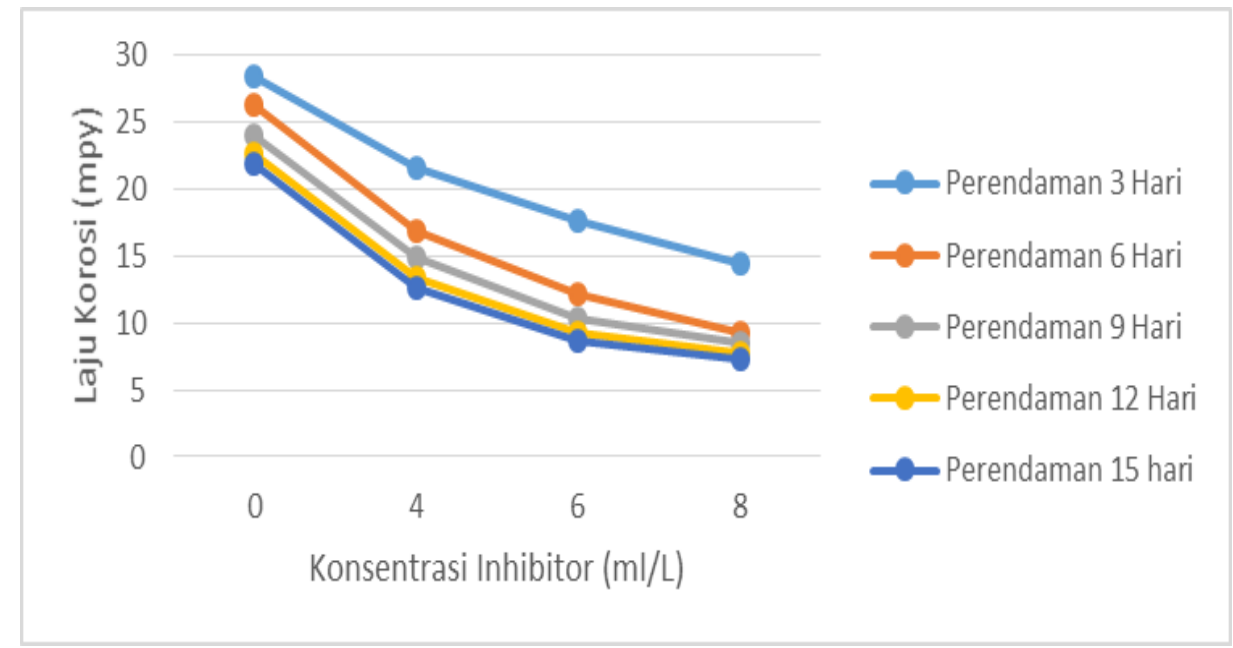

Gambar 2. Grafik Pengaruh konsentrasi ekstrak daun tembakau terhadap laju korosi baja dalam limgkungan asam

Tahap pengujian selanjutnya adalah pengaruh penambahan ekstrak daun tembakau terhadap efisiensi inhibitor. Inhibitor ekstrak daun tembakau mempengaruhi seluruh permukaan baja karbon rendah yang terkorosi jika konsentrasinya mencukupi. Inhibitor ini membentuk lapisan tipis pada permukaan baja karbon rendah sehingga melindungi baja karbon rendah (Ishak Ibrahim 2004). Dari data yang didapat menunjukkan bahwa penggunaan inhibitor ini cukup efektif, karena bisa menurunkan laju korosi secara cepat. Pengaruh konsentrasi ekstrak daun tembakau terhadap efisiensi inhibisi diperlihatkan pada Gambar 3.

Grafik dalam gambar 3, menunjukkan bahwa efisiensi inhibisi ekstrak daun tembakau meningkat secara signifikan dengan peningkatan konsentrasi dan waktu perendaman. Semakin besar konsentrasi semakin tinggi pula efisiensi yang didapat. Pada perendaman 3 hari dengan konsentrasi ekstrak daun tembakau 4 $\mathrm{ml} / \mathrm{L}$ efisiensi yang didapat $24,05 \%$, dan pada konsentrasi ekstrak daun tembakau 
$8 \mathrm{ml} / \mathrm{L}$ meningkat menjadi 49,35\%. Pada perendaman 15 hari dengan konsentrasi esktrak daun tembakau $4 \mathrm{ml} / \mathrm{L}$ efisiensi yang didapat $42,20 \%$, dan pada konsentrasi ekstrak daun tembakau $8 \mathrm{ml} / \mathrm{L}$ meningkat menjadi 66,27\%.

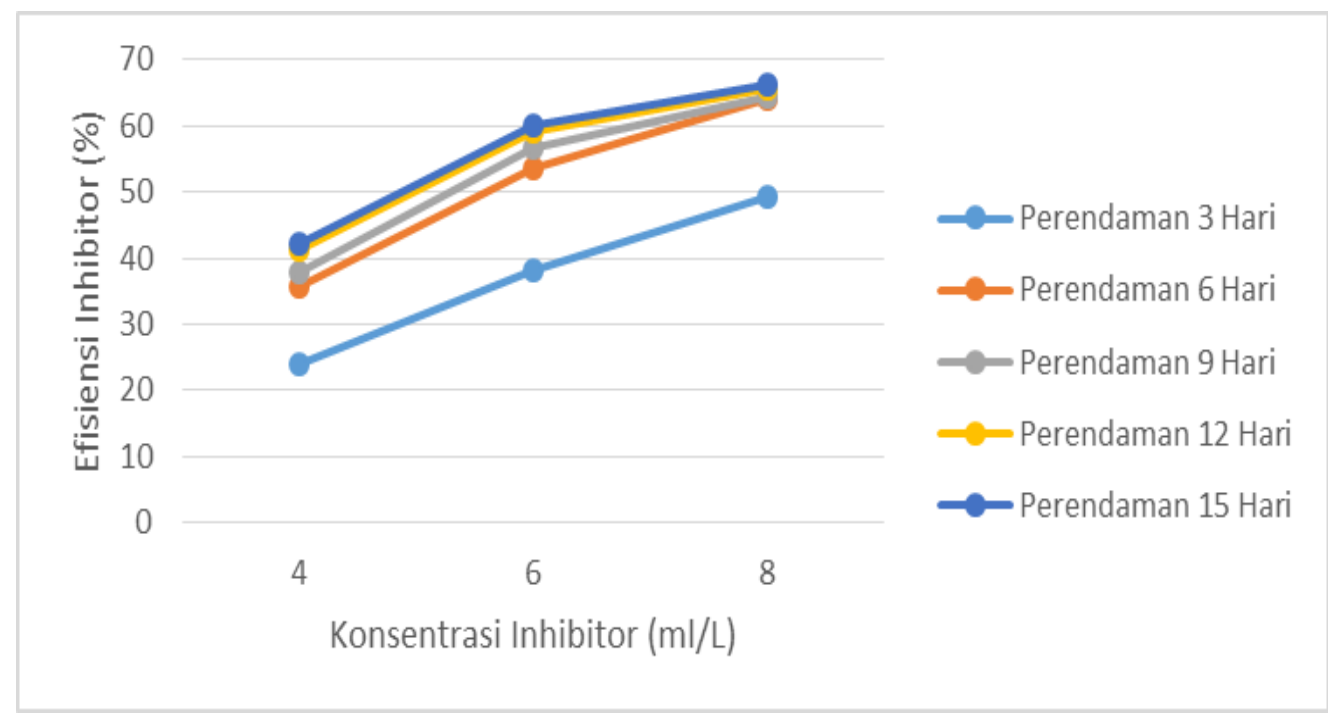

Gambar 3. Grafik Pengaruh konsentrasi ekstrak daun tembakau terhadap efisiensi inhibisi

Ekstrak daun tembakau merupakan larutan basa lemah dengan $\mathrm{pH}=8$. Pada analisa pengukuran kadar $\mathrm{pH}$ larutan pengkorosif yang merupakan larutan asam sulfat dengan $\mathrm{pH}=5$ (asam lemah), setelah ditambahkan inhibitor ekstrak daun tembakau sebanyak $4 \mathrm{ml} \mathrm{pH}$ tidak mengalami perubahan, pada saat penambahan inhibitor ekstrak daun tembakau sebanyak $6 \mathrm{ml}$ pada larutan pengkorosif terjadi perubahan $\mathrm{pH}$ menjadi 5,5 (asam lemah). Pada penambahan inhibitor ekstrak tembakau sebanyak 8ml, larutan pengkorosif terjadi perubahan pH menjadi 6 (asam lemah). Perubahan pH pada larutan pengkorosif disebabkan oleh penambahan inhibitor ekstrak daun tembakau yang merupakan basa lemah $(\mathrm{pH}=8)$. Semakin tinggi $\mathrm{pH}$ larutan maka akan terjadi pembentukan lapisan tipis (film) dipermukaan baja (fase pasif) sehingga menghambat kontak langsung antara baja dan lingkungan. Kalau baja dalam lingkungan $\mathrm{pH}=8$, dalam peta Pourbaix Diagram berada dalam wilayah pasif. 


\section{Kesimpulan}

Setelah melakukan pengolahan dan analisia data, maka penulis dapat mengambil kesimpulan:

1. Berdasarkan hasil penelitian ini ekstrak daun daun tembakau dapat dijadikan sebagai inhibitor baja karbon, dan menurunkan laju korosi secara siknifikan dalam larutan asam sulfat.

2. Pengaruh waktu perendaman baja karbon dalam larutan asam sulfat dengan penambahan inhibitor ekstrak daun tembakau diperoleh hasil terbaik pada perendaman 15 hari dan penambahan inhibitor $8 \mathrm{ml} / \mathrm{L}$ dengan laju korosi terendah sebesar 7,37 mpy.

3. Efisiensi inhibitor tertinggi dalam penelitian ini diperoleh pada perendaman baja karbon dalam larutan asam sulfat selama 15 hari dan inhibitor ekstrak daun tembakau $8 \mathrm{ml} / \mathrm{L}$ larutan yaitu 66,27\%.

4. Penggunaan ekstrak daun tembakau menggeser $\mathrm{pH}$ larutan ke wilayah alkali/basa sehingga logam baja karbon berada dalam wilayah pasif.

\section{Daftar Pustaka}

Asdim, 2001, Pengaruh Senyawa Alkilamin Terhadap Korosi Baja Dalam Larutan Asam Sulfat. [Tesis]. Pascasarjana UNAND. Padang.

Ishak, Jalaluddin, Fauziah, 2014, Ekstrak buah pinang (Areca catheculin) sebagai inhibitor korosi baja lunak dalam air laut. Jurusan Teknik Kimia, Fakultas Teknik, Universitas Malikussaleh

Denny A Jones, U.R,1972, Principles and prevention of corrosion, H.p, 1992, Macmillan Publishing Company, New York.

Evans, U.R,1972, Mechanism of Rushing Under Different Condition, J. Corrotion Rieger, H.p, 1992, Electrochemistry 2nd.ed. Chapman and Hall Inc.New York.

Ishak Ibrahim, 2004, Studi Mekanisme $\mathrm{Na}_{2} \mathrm{CrO}_{3}$ menghibisi SCC baja tahan karat AISI 304 tersensitisasi dalam larutan $\mathrm{H}_{2} \mathrm{SO}_{4}$. Jurusan Teknik Kimia, Fakultas Teknik Universitas Malikussalah.

Karim, Azis Abd. Dan Zulkifly A. Yusuf., 2012. “Analisa Pengaruh Penambahan Inhibitor Kalsium Karbonat dan Tapioka Terhadap Tingkat Laju Korosi 
pada Pelat Baja Tangki Ballast Air Laut”. Jurnal Riset dan Teknologi Kelautan (JRTK) 10 (7): 205-212.

Pattireuw, Kevin Jones, Fentje Abdul Rauf, dan Romels Cresano., 2013. Analisis Laju Korosi pada Baja Karbon dengan Menggunakan Air Laut dan $\mathrm{H}_{2} \mathrm{SO}_{4}$. Teknik Mesin. Manado: Universitas Sam Ratulangi.

Tretheway, Kr., Chamberlain J., 1991., Korosi untuk Mahasiswa dan Rekayasawan. Jakarta: PT. Gramedia Pustaka Utama.

Widharto, S., 2004. Karat dan Pencegahannya, Edisi Ketiga, PT. Pradnya Paramita, Jakarta.

Yuliarti, Iftitahul F., 2016. Pengaruh Penambahan Tapioka pada Inhibitor Ekstrak Daun Jambu Biji (Psidium guajava 1.) terhadap Efisiensi Inhibisi Korosi Baja Api 5L grade B pada Lingkungan $\mathrm{pH}=4$ dan $\mathrm{pH}=7$. Tugas Akhir. Surabaya: Jurusan Teknik Material dan Metalurgi, Fakultas Teknik Industri Institut Teknologi Sepuluh Nopember. 